\title{
Adjuvant radiotherapy with brachytherapy boost in soft tissue sarcomas
}

\author{
Annalisa Cortesi, MD!, Andrea Galuppi, MD!', Rezarta Frakulli, MD!, Alessandra Arcelli, MD!, Fabrizio Romani, PhD²,

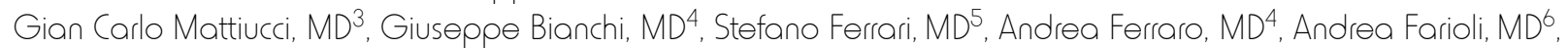

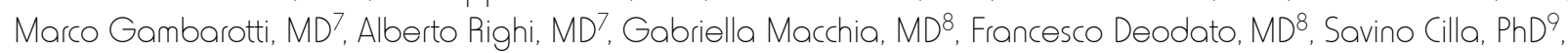 \\ Milly Buwenge, MSc', Vincenzo Valentini, MD³, Alessio Giuseppe Morganti, MD', Davide Donati, MD4, Silvia Cammelli, MD' \\ IRadiation Oncology Unit, Department of Experimental, Diagnostic and Specialty Medicine - DIMES, University of Bologna, S. Orsola- \\ Malpighi Hospital, Bologna, ${ }^{2}$ Medical Physic Unit, Policlinico S. Orsola-Maplighi, Bologna, ${ }^{3}$ Department of Radiotherapy, Policlinico \\ Universitario "A. Gemelli", Università Cattolica del Sacro Cuore, Rome, ${ }^{4}$ Clinica Ortopedica, Istituto Ortopedico Rizzoli, Via Pupilli I, Bologna, \\ ${ }^{5}$ Department of Oncology, Rizzoli Institute, Bologna, ${ }^{6}$ Department of Medical and Surgical Sciences (DIMEC), University of Bologna, S. Orsola- \\ Malpighi Hospital, Bologna, ${ }^{7}$ Department of Pathology, Istituto Ortopedico Rizzoli, Via Pupilli I, Bologna, ${ }^{8}$ Radiotherapy Unit, Fondazione \\ di Ricerca e Cura "Giovanni Paolo Il", Catholic University of Sacred Heart, Campobasso, 9 Medical Physic Unit, Fondazione di Ricerca e Cura \\ "Giovanni Paolo II", Catholic University of Sacred Heart, Campobasso, Italy
}

\begin{abstract}
Purpose: The standard primary treatment for soft tissue sarcoma (STS) is a wide surgical resection, preceded or followed by radiotherapy. Purpose of this retrospective study was to assess the efficacy of perioperative brachytherapy (BRT) plus postoperative external beam radiation therapy (EBRT) in patients with intermediate-high risk STS.

Material and methods: BRT delivered dose was $20 \mathrm{~Gy}$. External beam radiation therapy was delivered with 3D-technique using multiple beams. The prescribed dose was 46 Gy to the PTV. Neoadjuvant and adjuvant chemotherapy (CHT) was used in patients with potentially chemosensitive histological subtypes. The primary aim of the study was to analyze overall survival (OS) and local control (LC) in a large patient population treated with surgery, perioperative $\mathrm{BRT}$, and adjuvant EBRT $\pm \mathrm{CHT}$. Secondary objective was to identify prognostic factors for patients outcome in terms of LC, disease-free survival (DFS), and OS.

Results: From 2000 to 2011, 107 patients presenting 2-3 grade (FNLCC) primary or recurrent STS were treated with surgery, perioperative BRT, and adjuvant EBRT \pm CHT. Five-year LC and OS were $80.9 \%$ and $87.4 \%$, respectively. At univariate analysis, a higher LC was recorded in primary vs. recurrent tumors $(p=0.015)$, and in lower limb tumors vs. other sites $(p=0.027)$. An improved DFS was recorded in patients with lower limb tumors vs. other sites $(p=0.034)$.

Conclusions: The combination of BRT and EBRT was able to achieve satisfactory results even in a patients population with intermediate-high risk STS. Patients with recurrent or other than lower limb sited tumors show a worse LC.

J Contemp Brachytherapy 2017; 9, 3: 256-262 DOI: https://doi.org/10.5114/jcb.2017.68215
\end{abstract}

Key words: boost, brachytherapy, external beam radiotherapy, soft tissue sarcoma.

\section{Purpose}

Soft tissue sarcoma (STS) represents $1 \%$ of all adult malignancies and $15 \%$ of pediatric ones. In 2016, 12,310 people will be diagnosed with STS in USA [1].

Postoperative external beam radiation therapy (EBRT) is considered a standard treatment option. In fact, postoperative EBRT reduces local recurrence rate compared with surgery alone [2,3]. Furthermore, the use of EBRT achieves the same survival as radical surgery, without the cost of major functional impairment from amputation or extended resection [4].
Some of published experiences seems to suggest that the use of a boost with brachytherapy (BRT) can further improve local control rate achievable with adjuvant EBRT $[5,6,7,8,9,10,11,12]$.

Unfortunately, there is a little evidence in literature on the role of BRT. In fact, most available studies are retrospective and analyze limited number of patients $[8,13,14,15,16,17]$. Furthermore, these studies included patients with different risk categories (low, intermediate, high). Large series on BRT boost in adjuvant setting are still necessary to define the optimal treatment schedule [18]. Therefore, the purpose of this study was to consec-
Address for correspondence: Rezarta Frakulli, MD, Radiation Oncology Center, Department of Experimental, Diagnostic and Specialty Medicine - DIMES, University of Bologna, S. Orsola-Malpighi Hospital, via Giuseppe Massarenti 9, 40138, Bologna, Italy, phone: +39 051-6363154, fax: +39 051-6364336, e-mail: rezarta.frakulli@gmail.com
Received: 01.11.2016

Accepted: 25.02.2017

Published: 30.06.2017 
utively and homogeneously analyze a large population of patients treated with surgery, followed by adjuvant EBRT and BRT boost.

\section{Material and methods}

\section{Study design}

Medical patients charts, presenting grade 2-3 according to FNLCC (French Fédération Nationale des Centres de Lutte contre le Cancer) system [19], primary or recurrent deep STS of extremities or trunk treated with surgery and perioperative BRT followed by adjuvant EBRT \pm CHT were retrospectively analyzed. Patients receiving unplanned surgery were excluded.

\section{Patients characteristics}

One hundred and seven patients (median age: 54 years; range: 13-85), treated from January 2000 to January 2011 for high grade primary or recurrent STS were included in this retrospective analysis. Patient and tumor characteristics are shown in Table 1. Median follow-up was 100 months (range: 48-176).

\section{End points}

The primary end point of the study was to analyze overall survival (OS). Secondary end point was to identify prognostic factors of patients outcome in terms of local control (LC), metastasis-free survival (MFS), and diseasefree survival (DFS).

\section{Staging}

Biopsy was always requested before surgery. Before treatment, all patients underwent chest computed tomography (CT), contrast-enhanced magnetic resonance imaging (MRI), CT, and double contrast enhanced ultrasound of the affected site. The treatment started after histology assessment and staging completion.

\section{Surgery}

Surgical resection was performed according to the following criteria. The incision was made along the major axis of the tumor-bearing anatomical compartment and included the biopsy track en bloc. The quality of surgery was defined by its worst margins and was classified in intralesional, marginal, and wide according to Enneking classification [20]. Once the skin fat-flap was prepared, the tumor was isolated within the tumor-bearing structure and removed en bloc with the surrounding soft tissue, covered at every point by at least one centimeter of healthy tissue, or less if constituted by an anatomical barrier (fascia or periosteum).

\section{Brachytherapy}

At the time of surgical excision, the clinical target volume (CTV) of BRT was defined by surgical, pathological, and imaging findings. Surgical clips were placed at the margins of the tumor bed, and a minimum margin between clips and CTV was used. Placement of the cathe-
Table 1. Patients and treatment characteristics

\begin{tabular}{lcc} 
Parameter & $n$ & $\%$ \\
\hline Histology & & \\
\hline Undifferentiated pleomorphic sarcoma (UPS) & 27 & 25.2 \\
\hline Synovial sarcoma & 20 & 18.7 \\
\hline Myxofibrosarcoma & 13 & 12.1 \\
\hline Liposarcoma & 19 & 17.8 \\
\hline Leiomyosarcoma & 11 & 10.3 \\
\hline Other & 17 & 15.9 \\
\hline Tumor & & \\
\hline Primary & 44 & 41.1 \\
\hline Recurrent & 63 & 58.9
\end{tabular}

\section{Surgical margins}

\begin{tabular}{lcc}
\hline Wide & 72 & 67.3 \\
\hline Marginal & 29 & 27.1 \\
\hline Intralesional & 6 & 5.6
\end{tabular}

\begin{tabular}{lcc}
\hline Gender & 56 & 52.3 \\
\hline Male & 51 & 47.7
\end{tabular}

\begin{tabular}{lll}
\hline Age $(y)$ & & \\
\hline$\leq 54$ & 54 & 50.5 \\
\hline$>54$ & 53 & 49.5 \\
\hline Site & & \\
\hline
\end{tabular}

\begin{tabular}{lcc}
\hline Upper limb & 34 & 31.8 \\
\hline Lower limb & 64 & 59.8 \\
\hline Other & 9 & 8.4 \\
\hline
\end{tabular}

pT

\begin{tabular}{lll}
\hline $\mathrm{T} 1 \mathrm{~b}$ & 48 & 44.9 \\
\hline $\mathrm{T} 2 \mathrm{~b}$ & 59 & 55.1
\end{tabular}

\begin{tabular}{lcc}
\hline Grade & & \\
\hline 2 & 10 & 9.4 \\
\hline 3 & 97 & 90.6
\end{tabular}

Neoadjuvant chemotherapy

\begin{tabular}{lcc}
\hline No & 89 & 83.2 \\
\hline Yes & 18 & 16.8 \\
\hline Adjuvant chemotherapy & & \\
\hline No & 82 & 76.6 \\
\hline Yes & 25 & 23.4
\end{tabular}


ters and hollow needles were inserted through the skin and soft tissue parallel or perpendicular to the incision. The distance between the wound incision and the catheter entry point was $1-2 \mathrm{~cm}$. Needles were replaced with BRT catheters with $1-1.5 \mathrm{~cm}$ intervals to ensure adequate dosimetry. Catheters could be opened at one or both ends, blind-ended, and terminated with the wound. Once the catheters were in situ with the wound closed, an adequate space $(0.5 \mathrm{~cm})$ between the catheter buttons and the skin was ensured for postoperative edema. Dummy ribbons as anatomical landmarks and potential source positions were inserted before a planning CT (sliced obtained at $5 \mathrm{~mm}$ intervals) performed 1 week after surgical resection. Catheters were individually numbered. The ribbon reconstruction allowed to identify the basal points where the dose distribution was calculated.

Treatment planning was performed using computerbased optimization algorithms. Once the dosimetry was completed, the prescription dose was delivered to the CTV. The treatment time was determined based on prescribed dose and dose rate. In low-dose-rate (LDR) (2001-2003) and pulsed-dose-rate (PDR) (2004-2011), the median peripheral dose rate, defined as the lowest continuous isodose rate line covering the CTV was identified. This was generally $5 \mathrm{~mm}$ from the plane of the implant. The CTV $\mathrm{D}_{60 \%}, \mathrm{D}_{80 \%}, \mathrm{D}_{100 \%}$, $\mathrm{D}_{120 \%}, \mathrm{D}_{140 \%}, \mathrm{D}_{160 \%}$ (the minimum dose to $60-160 \%$ ) of the CTV were always reported. Once the treatment planning was calculated and the dose distribution was evaluated and accepted, the catheters were connected to a projection sources of Iridium-192 and the dose was delivered through the automatic loading of miniaturized sources.

The delivered dose was 20 Gy at dose-rate of 0.30 $0.80 \mathrm{~Gy} /$ hour, and $0.80 \mathrm{~Gy} /$ pulse for LDR and PDR, respectively. The treatment lasted 24-30 hours and 24 hours for LDR and PDR, respectively. A hospitalization for 1-2 day was necessary. Once the treatment was completed, the catheters were removed.

\section{External beam radiation therapy}

Simulation was generally performed 3-4 weeks after surgical resection, 2-3 weeks after brachytherapy treatment. Patients were immobilized in supine or prone position with different immobilization devices, such as vacuum cushions, cradle devices, feetstep (feet support cushion), or kneestep (knee support cushions). Planning CT slices for each patient were obtained at 5-mm intervals, including the surgical wound with adequate margins.

Patients underwent a pre-operative MRI-scan, which was co-registered, if possible, with the planning CT scan for delineation of target volumes and normal tissues including the organs at risk (OAR). The CTV was identified by planning CT and preoperative MRI, and was defined as the tumor and surgical bed, including the scar and the drainage site, adding $3 \mathrm{~cm}$ longitudinally and $1 \mathrm{~cm}$ radially. These margins were reduced at surfaces of fascia and bones, unless invaded.

CTV was expanded into planning target volume (PTV) by adding an isotropic $1-\mathrm{cm}$ margin to account for uncertainties setup. Also OAR (bones, joints, testi- cles, bladder, rectum, intestine for low extremities STS; bones and lung for upper extremities STS) were delineated. 3D conformal radiotherapy plans were generated with the requirement that at least $95 \%$ of the PTV should receive $95 \%$ of the prescribed dose. To prevent lymphedema, a "soft tissue strip/corridor" was identified to avoid irradiation of the extremities entire circumference. Isodose distributions in three planes (axial, sagittal, coronal) and cumulative dose-volume histograms of PTV and OAR were used to guide plan optimization.

The prescribed dose was 46 Gy to the PTV, delivered over 23 daily fractions (2 Gy/fraction). A multiple beams technique was used in order to achieve the best PTV coverage, while reducing irradiation of OARs and avoiding irradiation of contralateral limb (in case of lower limbs STS). All patients were treated with 6-18 MV X-rays from linear accelerators equipped with multileaf collimators with 1-cm leaf width at the isocenter. To ensure the correct positioning, patient setup was checked at least on a weekly basis by using electronic portal images device. Deviations $>5 \mathrm{~mm}$ were immediately corrected. External beam radiation therapy started within 90 days after surgery.

\section{Chemotherapy}

Neoadjuvant and adjuvant chemotherapy (CHT) consisted of epirubicin $\left(60 \mathrm{mg} / \mathrm{m}^{2} /\right.$ day, short infusion, days $1-2)$ and ifosfamide ( $3 \mathrm{~g} / \mathrm{m}^{2} /$ day, days $\left.1-2-3\right)$ were prescribed to those patients with potentially chemosensitive histological subtypes. The number of $\mathrm{CHT}$ cycles ranged between 3 and 5 . In case of neoadjuvant chemotherapy, surgery was performed at the end of the last cycle, after recovery from hematological toxicity and instrumental restaging. External beam radiation therapy was performed at the end of adjuvant CHT after the recovery from bone marrow toxicity. In the interval periods, prophylactic use of granulocyte colony-stimulating factor (G-CSF) was recommended. The interval between adjuvant $\mathrm{CHT}$ and EBRT was assessed case by case, depending on the hematological toxicity manifested by each individual patient.

\section{Dose modifications}

According to hematological toxicity, the following recommendations for dose adjustment were provided. Grade $0-1$ toxicity did not require $\mathrm{CHT}$ dose reductions. If grade 2 toxicity was registered, a $25 \% \mathrm{CHT}$ dose reduction was recommended and G-CSF were prescribed. In case of grade 3-4 toxicity, CHT was interrupted until recovery of toxicity to the grade $\leq 2$. External beam radiation therapy was interrupted only in case of grade 3-4 toxicity, until recovery of toxicity to grade $\leq 2$.

\section{Follow-up}

Patients were evaluated 3 weeks after RT or CHT completion, every 3 months thereafter for the first 2 years, then every 6 months for the first 5 years, and later annually. Patients evaluation included history and physical examination, blood tests of metabolic panel and hematological 
profile, ECOG status, and toxicity assessment. Chest CT and a contrast-enhanced MRI, CT, and double contrast enhanced ultrasound of the affected site were performed 3 months after the treatment and every 6 months for the first 5 years.

\section{Statistical analysis}

Statistical analysis was performed using SYSTAT, version 11.0 (SPSS, Chicago, IL). Univariate analyses were performed to evaluate individual risk factors. For each variables

Table 2. Univariate analysis (5-year results)

\begin{tabular}{|c|c|c|c|c|c|c|c|c|c|}
\hline Parameter & $\begin{array}{l}\mathrm{Nr} \\
\text { Pts }\end{array}$ & $\begin{array}{l}\text { Local } \\
\text { control }\end{array}$ & $p$ & $\begin{array}{c}\text { Metastases- } \\
\text { free } \\
\text { survival }\end{array}$ & $p$ & $\begin{array}{l}\text { Disease- } \\
\text { free } \\
\text { survival }\end{array}$ & $p$ & $\begin{array}{l}\text { Overall } \\
\text { survival }\end{array}$ & $p$ \\
\hline \multicolumn{10}{|l|}{ Group } \\
\hline Primary & 44 & 90.9 & \multirow[t]{2}{*}{0.015} & 63.4 & \multirow[t]{2}{*}{0.123} & 60.2 & \multirow[t]{2}{*}{0.848} & 95.2 & \multirow[t]{2}{*}{0.342} \\
\hline Recurrent & 63 & 74.2 & & 74.2 & & 57.6 & & 82.6 & \\
\hline \multicolumn{10}{|l|}{ Histology } \\
\hline UPS & 27 & 95.8 & \multirow[t]{6}{*}{0.125} & 62.4 & \multirow[t]{6}{*}{0.284} & 62.4 & \multirow[t]{6}{*}{0.895} & 82.9 & \multirow[t]{6}{*}{0.069} \\
\hline Synovial sarcoma & 20 & 85.0 & & 67.8 & & 58.3 & & 82.1 & \\
\hline Myxofibrosarcoma & 13 & 68.4 & & 83.9 & & 60.6 & & 100.0 & \\
\hline Liposarcoma & 19 & 71.9 & & 81.2 & & 53.8 & & 100.0 & \\
\hline Leiomyosarcoma & 11 & 90.9 & & 63.6 & & 63.6 & & 72.7 & \\
\hline Other & 17 & 68.4 & & 64.9 & & 55.4 & & 90.9 & \\
\hline \multicolumn{10}{|l|}{ Margins } \\
\hline Wide & 72 & 86.1 & \multirow[t]{3}{*}{0.075} & 73.6 & \multirow[t]{3}{*}{0.626} & 63.3 & \multirow[t]{3}{*}{0.369} & 91.6 & \multirow[t]{3}{*}{0.259} \\
\hline Marginal & 29 & 70.5 & & 61.0 & & 48.2 & & 77.9 & \\
\hline Intralesional & 6 & 66.7 & & 67.7 & & 50.0 & & 83.3 & \\
\hline \multicolumn{10}{|l|}{ Gender } \\
\hline Male & 56 & 83.0 & \multirow[t]{2}{*}{0.392} & 71.3 & \multirow[t]{2}{*}{0.755} & 59.3 & \multirow[t]{2}{*}{0.864} & 86.7 & \multirow[t]{2}{*}{0.858} \\
\hline Female & 51 & 78.5 & & 68.4 & & 58.0 & & 88.2 & \\
\hline \multicolumn{10}{|l|}{ Age } \\
\hline$\leq 54$ & 54 & 79.5 & \multirow[t]{2}{*}{0.700} & 68.1 & \multirow[t]{2}{*}{0.814} & 56.2 & \multirow[t]{2}{*}{0.800} & 91.2 & 0.196 \\
\hline$>54$ & 53 & 82.7 & & 72.3 & & 62.0 & & 82.8 & \\
\hline Site & & & & & & & & & \\
\hline Upper limb & 34 & 64.7 & 0.027 & 61.5 & 0.370 & 38.4 & 0.034 & 77.9 & 0.422 \\
\hline Lower limb & 64 & 90.1 & & 75.8 & & 71.0 & & 89.8 & \\
\hline Trunk & 9 & 74.1 & & 55.6 & & 41.7 & & 100.0 & \\
\hline Grade & & & & & & & & & \\
\hline 2 & 10 & 67.5 & 0.203 & 88.9 & 0.202 & 56.3 & 0.980 & 83.3 & 0.794 \\
\hline 3 & 97 & 82.2 & & 67.9 & & 58.7 & & 87.6 & \\
\hline pT & & & & & & & & & \\
\hline $\mathrm{T} 1 \mathrm{~b}$ & 48 & 76.9 & 0.420 & 75.8 & 0.115 & 62.2 & 0.283 & 81.6 & 0.195 \\
\hline $\mathrm{T} 2 \mathrm{~b}$ & 59 & 84.3 & & 65.3 & & 56.0 & & 92.4 & \\
\hline Stage & & & & & & & & & \\
\hline II & 49 & 75.3 & 0.196 & 76.2 & 0.092 & 60.9 & 0.421 & 81.7 & 0.201 \\
\hline III & 58 & 85.8 & & 64.8 & & 57.0 & & 92.3 & \\
\hline CT Pre & & & & & & & & & \\
\hline No & 89 & 81.5 & 0.361 & 69.7 & 0.960 & 58.2 & 0.656 & 88.6 & 0.245 \\
\hline Yes & 18 & 76.9 & & 70.5 & & 60.6 & & 81.0 & \\
\hline CT Post & & & & & & & & & \\
\hline No & 82 & 78.8 & 0.389 & 74.3 & 0.147 & 60.7 & 0.575 & 89.4 & 0.244 \\
\hline Yes & 25 & 87.8 & & 54.9 & & 52.1 & & 81.3 & \\
\hline
\end{tabular}

CT - chemotherapy, UPS - undifferentiated pleomorphic sarcoma 
category, LC, MFS, DFS, and OS were estimated according to the Kaplan-Meier method, and the log-rank test was used to compare survival curves. Multivariable analysis was not conducted when investigating local control or death due to the limited number of events (19 and 13, respectively). For disease-free survival, multivariable analysis were not conducted because only one predictor (namely, site), reached the statistical significance threshold $(p<0.10)$ established a priori. When studying metastases-free survival, there was no predictor reaching the statistical threshold.

The differences were considered statistically significant if the $p$-value was $<0.05$.

\section{Results}

\section{Patients outcome}

1-year and 3-year LC were $96.2 \%$ and $86.3 \%$, respectively. Overall, 5-year LC was $80.9 \%$ : $90.9 \%$ for primary STS and $74.2 \%$ for recurrent tumor. Three-year and 5-year MFS, DFS, and OS were $76.9 \%, 69.4 \%, 95.1 \%$, and $69.8 \%, 58.6 \%$, $87.4 \%$, respectively. Overall, during follow-up, 19 patients developed local recurrence, 30 patients distant metastases, 42 patients relapse events, and 13 patients died.

\section{Univariate analysis}

Table 2 shows the results of the univariate analysis. A higher LC rate was recorded in patients treated for primary sarcomas compared to recurrent tumors. Patients with lower limbs STS showed a better 5-year LC compared to upper limbs or trunk sarcomas. A trend between LC and margin status was also recorded with higher LC rate in patients with wide surgical margins. The other analyzed parameters did not show a significant correlation or trend with LC. Disease-free survival was significantly correlated to the disease site: 5 -year DFS was $71.0 \%$ for lower limbs, and $38.4 \%$ and $41.7 \%$ for upper-limb and trunk tumors,

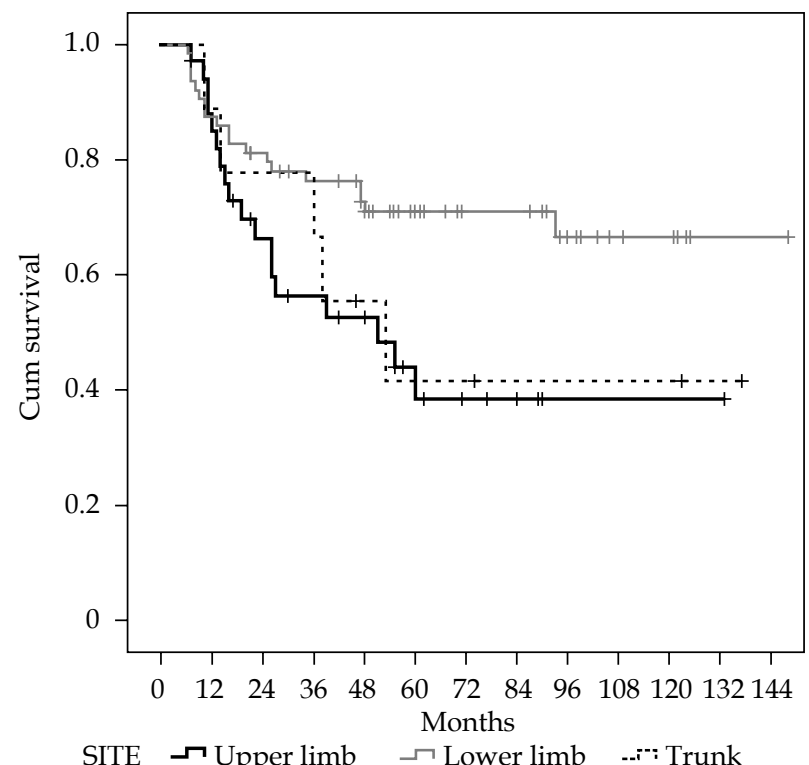

Fig. 1. Actuarial disease-free survival correlated to the disease site respectively (Figure 1). A trend was observed between histology and OS ( $p=0.069)$ with myxofibrosarcoma and liposarcoma showing a better survival. Leiomyosarcoma showed a high LC rate (5-year LC, 90.9\%) while showing a relatively poor outcome in terms of OS (5-year OS, 72.7\%).

\section{Discussion}

Our study was performed in order to assess the impact of adjuvant EBRT and anticipated BRT boost on LC in patients with STS. To the best of our knowledge, it is the largest series on adjuvant EBRT plus BRT boost in STS.

This study has the limitation of a retrospective assessment, variable use of chemotherapy, and absence of data on acute and late toxicities. Moreover, patients recruitment took place over a long period of time (10 years). This could have reduced the homogeneity in patients management due to evolution of staging and treatment techniques. Furthermore, data about treatment interruption or delay are missing. However, all patients were followed by the same team of radiologists, radiation oncologists, surgeons, and medical oncologists and all patients underwent the same type of combined treatment (BRT + EBRT) with uniform doses.

We should admit that preoperative RT is able to reduce late morbidity compared to postoperative RT [21], and that BRT has very limited role in STS in the present intensity modulated RT era. However, being postoperative RT still used in several centers, we presented our large series of patients with prolonged follow-up. In our study, as expected, a correlation was observed between tumor type (primary vs. recurrent) and LC (90.9\% vs. $74.2 \% ; p=0.015)$, without a significant impact on MFS, DFS, and OS. The same significant correlation between tumor type and LC was found in other publications. Petera et al. [12] examined the results of 34 patients with STS, treated between 1998 and 2007 with HDR-BRT (mean dose 24 Gy; 15-30 Gy) and EBRT (40-50 Gy), showing that LC was $100 \%$ in primary tumors and $64 \%$ in recurrent lesions $(p=0.004)$. They observed a tendency toward more local recurrences in patients with a close/positive margin than in patients with a negative margin. Also in our study, a statistical trend was found with 5-year LC of $86.1 \%, 70.5 \%$, and $66.7 \%$ in patients with wide, marginal, and intralesional margins, respectively.

Another significant correlation recorded in our analysis was between tumor site (lower limb vs. upper limb and trunk), and LC and DFS. The worse results recorded in upper limb STS may depend on the greater difficulty of radical surgery in this dimensionally smaller and richer of neurovascular bundles area.

Table 3 shows the results of the comparison between other studies $[7,12,13,14,18,22]$ and our results. Local control and OS were similar to that recorded in other centers despite inclusion of intermediate-high grade (HG) STS only. On the contrary, in other published studies, the analyzed populations also included low grade (LG) STS, generally showing a better prognosis $[7,12,13,14,18,22]$. The favorable impact of adjuvant radiation therapy on LC compared to surgery alone has been shown in several studies $[7,12,13,14,18,22]$. However, it is more difficult to define 
Table 3. Literature results

\begin{tabular}{|c|c|c|c|c|c|c|c|c|c|}
\hline $\begin{array}{l}\text { Authors } \\
\text { (reference) }\end{array}$ & Center & $\begin{array}{l}\text { Median } \\
\text { follow- } \\
\text { up }\end{array}$ & $\begin{array}{l}\text { Inclusion } \\
\text { criteria }\end{array}$ & $\begin{array}{c}\text { No. of } \\
\text { patients }\end{array}$ & $\begin{array}{c}\text { EBRT } \\
\text { dose } \\
\text { (Gy) }\end{array}$ & $\begin{array}{l}\text { BRT } \\
\text { dose } \\
\text { (Gy) }\end{array}$ & $\begin{array}{l}\text { Chemo- } \\
\text { therapy }\end{array}$ & $\begin{array}{c}\text { 5-year local } \\
\text { control }\end{array}$ & $\begin{array}{c}\text { 5-year } \\
\text { overall } \\
\text { survival }\end{array}$ \\
\hline $\begin{array}{l}\text { Petera et al., } \\
2010 \text { [12] }\end{array}$ & $\begin{array}{l}\text { University } \\
\text { Hospital } \\
\text { Hradek } \\
\text { Kralovè, } \\
\text { Czech } \\
\text { Republic }\end{array}$ & $\begin{array}{c}38.4 \\
(3.6-114)\end{array}$ & $\begin{array}{l}\text { Primary }(17)+ \\
\text { recurrent }(28) ; \\
\text { Low risk }(20) ; \\
\text { Intermediate/ } \\
\text { high risk }(25)\end{array}$ & 45 & $40-50$ & $\begin{array}{l}\text { HDR (30-54; } \\
\text { median: } 40) \\
\text { in } 11 \text { pts. } \\
\text { HDR (15-30; } \\
\text { median: } 24) \\
\text { in } 34 \text { pts. }\end{array}$ & $+1-$ & $74 \%$ & $70 \%$ \\
\hline $\begin{array}{l}\text { Martinez- } \\
\text { Monge et al., } \\
2005[14]\end{array}$ & $\begin{array}{l}\text { University } \\
\text { of Navarra, } \\
\text { Pamplona, } \\
\text { Spain }\end{array}$ & $\begin{array}{c}23.2 \\
(2.8-48)\end{array}$ & $\begin{array}{l}\text { Primary }(24)+ \\
\text { recurrent (1); } \\
\text { Low risk (9); } \\
\text { Intermediate/ } \\
\text { high risk (16) }\end{array}$ & 25 & 45 & HDR 16-32 & $+1-$ & $\begin{array}{l}\text { 4-year: } \\
\text { 100\% local } \\
80.5 \% \\
\text { regional }\end{array}$ & $\begin{array}{l}\text { 4-year: } \\
78.2 \%\end{array}$ \\
\hline $\begin{array}{l}\text { Itami et al. } \\
2010[13]\end{array}$ & $\begin{array}{c}\text { National } \\
\text { Cancer Central } \\
\text { Hospital, } \\
\text { Tokyo, Japan }\end{array}$ & 49.7 & $\begin{array}{l}\text { Primary }(12)+ \\
\text { recurrent }(14) ; \\
\text { Margins +/-; } \\
\text { Low risk }(2) ; \\
\text { Intermediate/ } \\
\text { high risk }(24)\end{array}$ & 26 & - & HDR 36 & $+1-$ & $\begin{array}{c}78.2 \% \\
\text { (43.8\% recur- } \\
\text { rent + } \\
\text { pos. margins; } \\
\text { 93.3\% prim- } \\
\text { itive, } \\
\text { neg. margins) }\end{array}$ & $75.6 \%$ \\
\hline $\begin{array}{l}\text { Lazzaro } \\
\text { et al., } 2005 \\
{[7]}\end{array}$ & $\begin{array}{l}\text { IEO, Milano, } \\
\text { Italy }\end{array}$ & $\begin{array}{c}34 \\
(12-56)\end{array}$ & $\begin{array}{l}\text { Primary }(32)+ \\
\text { recurrent }(10) \text {; } \\
\text { Low risk }(7)+ \\
\text { intermediate/ } \\
\text { high risk }(35)\end{array}$ & 42 & $\begin{array}{c}50 \\
(40-66) \\
\text { in } 24 \text { pts }\end{array}$ & $\begin{array}{l}\text { PDR (45-60; } \\
\text { median: } 45) \\
\text { in } 18 \text { pts. } \\
\text { PDR (10-29; } \\
\text { median: } 15) \\
\text { in } 24 \text { pts. }\end{array}$ & $+/-$ & 3-year: 89\% & $\begin{array}{l}\text { 3-year: } \\
83.9 \%\end{array}$ \\
\hline $\begin{array}{l}\text { Andrews } \\
\text { et al., } 2004 \\
{[18]}\end{array}$ & $\begin{array}{c}\text { Fox Chase } \\
\text { Cancer Center, } \\
\text { Philadelphia, } \\
\text { USA }\end{array}$ & 62 & $\begin{array}{l}\text { Low risk (24); } \\
\text { Intermediate/ } \\
\text { high risk (48); } \\
\text { Unknown (14) }\end{array}$ & 86 & $\begin{array}{l}50(40-70) \\
\text { in } 25 \text { pts } \\
59(50-74) \\
\text { in } 61 \text { pts }\end{array}$ & $\begin{array}{l}\text { LDR (10-20; } \\
\text { median: } 16) \\
\text { in } 25 \text { pts. }\end{array}$ & $+1-$ & $\begin{array}{l}90 \% \\
83 \%\end{array}$ & $\begin{array}{l}82 \% \\
72 \%\end{array}$ \\
\hline $\begin{array}{l}\text { San Miguel } \\
\text { et al., } 2011 \\
{[22]}\end{array}$ & $\begin{array}{c}\text { Clınica } \\
\text { Universidad } \\
\text { de Navarra, } \\
\text { Spain }\end{array}$ & $\begin{array}{l}49.3 \\
(5.9- \\
107)\end{array}$ & $\begin{array}{l}\text { Primary }(50)+ \\
\text { recurrent }(10) \text {; } \\
\text { Low risk }(16) ; \\
\text { Intermediate/ } \\
\text { high risk }(44)\end{array}$ & 60 & 45 & HDR (16-24) & $+/-$ & $\begin{array}{l}\text { 9-year: } \\
77.4 \%\end{array}$ & $\begin{array}{l}\text { 9-year: } \\
61.5 \%\end{array}$ \\
\hline $\begin{array}{l}\text { Present } \\
\text { series }\end{array}$ & $\begin{array}{c}\text { Bologna, } \\
\text { University, } \\
\text { Italy }\end{array}$ & $\begin{array}{c}100 \\
(48-176)\end{array}$ & $\begin{array}{l}\text { Primary }(44)+ \\
\text { recurrent }(63) ; \\
\text { Intermediate/ } \\
\text { high risk (107) }\end{array}$ & 107 & 46 & $\begin{array}{l}\text { LDR/PDR } \\
(20)\end{array}$ & $+1-$ & $80.9 \%$ & $87.4 \%$ \\
\hline
\end{tabular}

EBRT-external beam radiation therapy, BRT-brachytherapy, HDR - high-dose-rate, $L D R$-low-dose-rate, $P D R$ - pulsed-dose rate

the role of BRT boost. In fact, only Andrews et al. [18] analyzed the difference in terms of LC and OS between patients treated with perioperative BRT followed by EBRT or EBRT alone, and reported an improved LC and OS in patients receiving a combined treatment. We can observe that several studies reporting on surgery plus postoperative EBRT recorded 5-year LC rates (75.5-87.0\%) similar to our series, where BRT boost was used (80.9\%). Nevertheless, we should stress again that some of these studies included even patients with low-grade disease [3,23,24,25,26,27]. Furthermore, two of these trials involved only patients with primary tumors $[3,24]$.

\section{Conclusions}

In conclusion, the results of this analysis show that a combination of BRT and EBRT is able to produce high LC and OS rates even in a patients population with intermediate-high risk STS. Therefore, this type of treatment could be proposed in patients with the same disease characteristics in combination with CHT in tumors with chemosensitive tumors.

Prospective studies on the use of BRT/EBRT with uniform radiation doses and large patient population in the adjuvant setting of STS are still needed to define the optimal treatment schedule. Particularly, based on our 
results, treatment intensification should be tested in patients with unfavorable prognostic factors (recurrent tumors and other than lower limb sites).

\section{Acknowledgement}

The research was conducted at Policlinico S. OrsolaMaplighi and Istituto Ortopedico Rizzoli, Bologna, Italy.

\section{Disclosure}

Authors report no conflict of interest.

\section{References}

1. Siegel RL, Miller KD, Jemal A. Cancer statistics 2016. CA Cancer J Clin 2016; 66: 7-30.

2. Yang JC, Chang AE, Baker AR et al. Randomized prospective study of the benefit of adjuvant radiation therapy in the treatment of soft tissue sarcomas of the extremity. J Clin Oncol 1998; 16: 197-203.

3. Jebsen NL, Trovik CS, Bauer HC et al. Radiotherapy to improve local control regardless of surgical margin and malignancy grade in extremity and trunk wall soft tissue sarcoma: a Scandinavian sarcoma group study. Int J Radiat Oncol Biol Phys 2008; 71: 1196-1203.

4. Rosenberg SA, Tepper J, Glatstein E et al. The treatment of soft-tissue sarcomas of the extremities: prospective randomized evaluations of (1) limb-sparing surgery plus radiation therapy compared with amputation and (2) the role of adjuvant chemotherapy. Ann Surg 1982; 196: 305-315.

5. Delannes M, Thomas L, Martel P et al. Low-dose-rate intraoperative brachytherapy combined with external beam irradiation in the conservative treatment of soft tissue sarcoma. Int J Radiat Oncol Biol Phys 2000; 47: 165-169.

6. Alektiar KM, Leung D, Zelefsky M et al. Adjuvant brachytherapy for primary high-grade soft tissue sarcoma of the extremity. Ann Surg Oncol 2002; 9: 48-56.

7. Lazzaro G, Lazzari R, Pelosi G et al. Pulsed dose-rate perioperative interstitial brachytherapy for soft tissue sarcomas of the extremities and skeletal muscles of the trunk. Ann Surg Oncol 2005; 12: 935-942.

8. Laskar S, Bahl G, Puri A et al. Perioperative interstitial brachytherapy for soft tissue sarcomas: prognostic factors and long-term results of 155 patients. Ann Surg Oncol 2007; 14: 560-567.

9. Pohar S, Haq R, Liu L et al. Adjuvant high-dose-rate and low dose-rate brachytherapy with external beam radiation in soft tissue sarcoma: a comparison of outcomes. Brachytherapy 2007; 6: 53-57.

10. Muhic A, Hovgaard D, Mørk Petersen M et al. Local control and survival in patients with soft tissue sarcomas treated with limb sparing surgery in combination with interstitial brachytherapy and external radiation. Radiother Oncol 2008; 88: 382-387.

11. Beltrami G, Rüdiger HA. Limb salvage surgery in combination with brachytherapy and external beam radiation for highgrade soft tissue sarcomas. Eur J Surg Oncol 2008; 34: 811-816.

12. Petera J, Soumarová R, Růzicková J et al. Perioperative hyperfractionated high-dose rate brachytherapy for the treatment of soft tissue sarcomas: multicentric experience. Ann Surg Oncol 2010; 17: 206-210.

13. Itami J, Sumi M, Beppu Y et al. High dose rate brachytherapy alone in postoperative soft tissue sarcomas with close or positive margins. Brachytherapy 2010; 9: 349-353.

14. Martinez-Monge R, San Julian M, Amillo S et al. Perioperative high-dose-rate brachytherapy in soft tissue sarcomas of the extremity and superficial trunk in adults: initial results of a pilot study. Brachytherapy 2005; 4: 264-270.

15. Pellizzon ACA, Nadalin W, Salvajoli JV et al. High dose rate brachytherapy as a boost in management of adult soft tissue sarcoma: results and complications. J B Int 2000; 17: 43-50.

16. Pellizzon ACA. Evidence and clinical outcomes of adult soft tissue sarcomas of the extremities treated with adjuvant high-dose-rate brachytherapy - a literature review. J Contemp Brachytherapy 2014; 6: 318-322.

17. Holloway CL, Delaney TF, Alektiar KM et al. American Brachytherapy Society (ABS) consensus statement for sarcoma brachytherapy. Brachytherapy 2013; 12: 179-190.

18. Andrews SF, Anderson PR, Eisenberg BL et al. Soft tissue sarcomas treated with postoperative external beam radiotherapy with and without low-dose-rate brachytherapy. Int J Radiat Oncol Biol Phys 2004; 59: 475-480.

19. Trojani M, Contesso G, Coindre JM et al. Soft-tissue sarcomas of adults; study of pathological prognostic variables and definition of a histopathological grading system. Int J Cancer 1984; 33: 37-42.

20. Enneking WF, Spanier SS, Goodman MA. A system for the surgical staging of musculoskeletal sarcoma. 1980. Clin Orthop Relat Res 2003; 415: 4-18.

21. Davis AM, O'Sullivan B, Turcotte $\mathrm{R}$ et al. Late radiation morbidity following randomization to preoperative versus postoperative radiotherapy in extremity soft tissue sarcoma. Radiother Oncol 2005; 75: 48-53.

22. San Miguel I, San Julián M, Cambeiro M et al. Determinants of toxicity, patterns of failure, and outcome among adult patients with soft tissue sarcomas of the extremity and superficial trunk treated with greater than conventional doses of perioperative high-dose-rate brachytherapy and external beam radiotherapy. Int J Radiat Oncol Biol Phys 2011; 81: e529-e539.

23. Alektiar KM, Velasco J, Zelefsky MJ et al. Adjuvant radiotherapy for margin-positive high-grade soft tissue sarcoma of the extremity. Int J Radiat Oncol Biol Phys 2000; 48: 1051-1058.

24. Zhao RP, Yu XL, Zhang Z et al. The efficacy of postoperative radiotherapy in localized primary soft tissue sarcoma treated with conservative surgery. Radiat Oncol 2016; 11: 25.

25. Delaney TF, Kepka L, Goldberg SI et al. Radiation therapy for control of soft-tissue sarcomas resected with positive margins. Int J Radiat Oncol Biol Phys 2007; 67: 1460-1469.

26. Fein DA, Lee WR, M. Lanciano RM et al. Management of extremity soft tissue sarcomas with limb sparing surgery and postoperative irradiation: Do total dose, overall treatment time, and the surgery-radiotherapy interval impact on local control? Int J Radiat Oncol Biol Phys 1995; 32: 969-976.

27. Mundt AJ, Awan A, Sibley GS et al. Conservative surgery and adjuvant radiation therapy in the management of adult soft tissue sarcoma of the extremities: clinical and radiobiological results. Int J Radiat Oncol Biol Phys 1995; 32: 977-985. 